\section{Assays to Assess Freeze Injury of Satsuma Mandarin}

\author{
Monte L. Nesbitt ${ }^{1}$ \\ Alabama Agricultural Experiment Station, GulfCoast Regional Research and \\ Extension Center, 8300 State Hwy. 104, Fairhope, AL 36532
}

\section{Robert C. Ebel' ${ }^{2}$, Douglas Findley ${ }^{2}$, Bryan Wilkins ${ }^{3}$, Floyd Woods ${ }^{4}$, and David Himelrick ${ }^{5}$ \\ Department of Horticulture, Auburn University, 101 Funchess Hall, Auburn, AL 36849}

Additional index words. Citrus unshiu, cold hardiness, electrolyte leakage, differential thermal analysis, triphenyl tetrazolium chloride, phenolic leakage, callus

\begin{abstract}
Containerized 'Owari' satsuma mandarin (Citrus unshiu Marc.) on Poncirus trifoliata 'Flying Dragon' rootstock were exposed to one of two acclimation regimes (cold acclimated and unacclimated) and frozen in a computer-controlled freezer to five different low temperatures. Whole plant survival was measured and compared to the results of four leaf and stem injury assays. Acclimating plants in growth chambers at $20{ }^{\circ} \mathrm{C}$ day and $10{ }^{\circ} \mathrm{C}$ night for 14 days, followed by $15{ }^{\circ} \mathrm{C}$ day and $4{ }^{\circ} \mathrm{C}$ night for 14 to 21 days resulted in an $81 \%$ and $80 \%$ increase in leaf and stem survival, respectively, when frozen to a low of $-8{ }^{\circ} \mathrm{C}$. Electrolyte leakage and phenolic leakage assays effectively detected changes in percent leaf survival, but the TTC stain assay, using leaf disks, did not. Stem survival was best predicted by the TTC assay, using the phloem as the indicator tissue for survival. Electrolyte leakage and phenolic leakage were also reliable assays for predicting stem survival, although survival percentages were different at the same electrolyte leakage values reported in other studies. The callus growth assay accurately predicted survival for cold acclimated satsuma mandarin stems only. Chemical name used: triphenyl tetrazolium chloride (TTC).
\end{abstract}

Satsuma mandarin Citrus unshiu (Marc.) is grown commercially along the northern Gulf of Mexico coast where damaging freezes are a perennial threat. The winter climate is characterized by wide and rapid fluctuations in temperatures. Citrus trees acclimate slowly and deacclimate rapidly in response to temperature (Yelenosky, 1978; Young, 1970), which affects cold hardiness. Cold hardiness is the ability of a plant or plant organ to resist freezing or survive freezing conditions (Fuchigami, 1996; Soule, 1985). Temperatures that cause cessation of active growth and enhance cold hardiness have been determined for satsuma mandarin and other citrus cultivars (Young and Peynado, 1962). Poncirus trifoliata (L.) Raf., one of the most common rootstocks used by the satsuma mandarin industry along the Gulf Coast, acclimates in as little as $6 \mathrm{~h}$ when exposed to $10^{\circ} \mathrm{C}$ (Tignor et al., 1997), but specific rates and extent of acclimation and deacclimation of other scion and rootstock cultivars are not completely documented. Monitoring changes in cold hardiness would help satsuma growers know when to implement protective measures (i.e., water sprinklers, orchard heaters, plant covers, etc.),

Received for publication 12 July 2001. Accepted for publication 30 Jan. 2002.

${ }^{1}$ Research Horticulturist.

${ }^{2}$ Assistant Professor.

${ }^{3}$ Field Research Associate III.

${ }^{4}$ Associate Professor.

${ }^{5}$ Professor. but monitoring changes in hardiness accurately is dependent upon identifying a reliable method of determining the freeze injury point of field-grown trees.

Electrolyte leakage. One of the most widely used assays for measuring freeze injury of plants is the electrolyte leakage method (EL), which measures the change in electrical conductance of a sample solution caused by diffusion of electrolytes out of damaged plant cells (Dexter et al., 1930, 1932). EL has been modified (Flint et al., 1967; Sukumaran and Weiser, 1972; Zhang and Willison, 1986), reviewed (Calkins and Swanson, 1990; Prasil and Zamecnik, 1998), and applied to many different species (Emmert and Howlett, 1953; Hallam and Tibbits, 1988), including citrus (Anderson, 1983; Ketchie, 1969; Ketchie et al., 1972; Tignor et al., 1997, 1998). Despite its popularity as a measure of damage to freezing temperatures, EL has several limitations. EL is an indirect measurement of cell injury. It does not distinguish leakage among tissues critical and noncritical for plant survival (Calkins and Swanson, 1990), nor between recoverable and unrecoverable injury (Palta et al., 1977). EL rates vary among species, and an arbitrary amount of electrolyte leakage, such as $50 \%$, should not be used as an indicator of death when whole plant response and regrowth at that level of leakage has not been evaluated (Stergios and Howell, 1973). Response curves have been generated for survival and EL of some citrus, including 'Keen' sour orange $(C$. aurantium $\mathrm{L}$.) and rough lemon $(C$. limon $\mathrm{L}$.
Burm. F.) (Ketchie et al., 1972), but response curves have not been reported for satsuma mandarin.

Phenolic leakage. Plant cell membranes leak UV-absorbing phenolic compounds in response to abiotic stress, such as salt (Redmann et al., 1986) or low temperature (ChalkerScott et al., 1989). Phenolics in the leachate may include those present prior to the stress event and synthesized after cellular disruption unites precursory products (Ting, 1982). Phenolic compounds measured with spectrophotometers at $260 \mathrm{~nm}$ were highly correlated with EL and visual injury ratings (ChalkerScott et al., 1989). The phenolic leakage assay (PL) differs from EL only in the solutes that are measured.

Callus assay. The growth of callus tissue on stems of several deciduous tree species has been demonstrated to be a useful assay for determining freeze injury (Pellett and Heleba, 1998). Callus forms from cambial tissue, is critical to the formation of new phloem and xylem, and is therefore critical for survival of stems after freezing. In a study of the callus growth (CG) assay on several deciduous tree species, most, but not all species produced readily visible callus within 5 to $10 \mathrm{~d}$ (Pellett and Heleba, 1998). The CG assay results consistently differed from EL in identification of damaging temperatures (Pellett and Heleba, 1998). The CG assay has not been previously compared to other freeze assessment assays on citrus.

Triphenyl tetrazolium chloride (TTC) Staining with 2,3,5-triphenyltetrazolium chloride (TTC) has been used to measure viability of citrus and other plant tissues after freezing or other forms of stress (Ketchie and Kammereck, 1987; Parker, 1953; Prive and Zhang, 1996; Purcell and Young, 1963; Schaff et al., 1987; Stergios and Howell, 1973). Living plant cells reduce TTC in their mitochondria, producing carmine-red to cherry-red formazan, but dead cells do not. Tissues can then be visually assessed for viability by subjectively classifying tissues as living or dead based on the appearance of red (Purcell and Young, 1963), or the formazan can be extracted and quantified with a spectrophotometer (Steponkus and Lanphear, 1967; Towill and Mazur, 1974). The principle disadvantage of extracting formazan is the inability to distinguish temperature effects on specific tissues. Furthermore, TTC extraction was shown in one study to be a poor indicator of freeze damage compared to EL and PL (ChalkerScott et al., 1989). Visual assessment of TTC reduction has been useful in some freeze injury studies (Prive and Zhang, 1996; Stergios and Howell, 1973), but it can be difficult to visually classify citrus tissues as alive or dead after a natural freeze because the degree of TTC reduction varies resulting in a wide variation in the extent and pattern of staining (Purcell and Young, 1963), and sometimes tissues that are initially stained will subsequently die (Parker, 1963). Nevertheless, TTC staining of stem cross sections provides information concerning survival of individual tissues, which more gross assays such as EL and PL do not, 
and therefore may be useful in some freeze damage studies.

Differential thermal analysis. Freeze injury has also been assessed by differential thermal analysis (DTA), which measures an electric current generated by a thermocouple when heat is released as ice forms compared to a reference thermocouple attached to a dried sample (Quamme et al., 1972). The pattern of ice formation is normally characterized by one or more significant freezing events, known as exotherms. Species vary in the number of exotherms produced as temperatures decline below freezing. Five woody, subtropical species produced only one exotherm, which made it difficult to distinguish between nonlethal, extracellular freezing and lethal, intracellular freezing (Kuroda et al., 1997). Ice propagates quickly along citrus stems, usually from a single site, and probably occurs as a result of ice formation in the xylem (Yelenosky, 1975). The starting point of ice formation depends on the degree of acclimation, and starts at the basal portion of the stem in acclimated plants, but at the distal portion of the stem in nonacclimated plants (Yelenosky, 1975). The principle disadvantage of using DTA to assess freeze injury of citrus stems is the poor correlation to field-observed hardiness (Yelenosky and Horanic, 1969). In fact, plant tissues are able to tolerate some ice formation without significant damage (Ketchie and Kammereck, 1987). Furthermore, more cold-sensitive citrus can freeze at lower temperatures than those that are more cold hardy, which we determined in preliminary tests where the exotherms produced by 'Owari' satsuma mandarin, 'Hamlin' sweet orange [Citrus sinensis (L.) Osb.], and P. trifoliata stems did not show an appropriate relationship to their established relative hardiness. Since research has shown that DTA is not a good indicator for cold hardiness of citrus, DTA was not measured in the current study.

An extensive comparison of various assays to assess tissue damage by subfreezing temperatures has not been conducted for citrus. This study was conducted to compare whole plant injury and survival of satsuma mandarin to measures of EL, PL, CG, and TTC. The characteristics of each assay are discussed with respect to use in physiological studies and the development of predictive hardiness models.

\section{Materials and Methods}

Plant culture and acclimation treatments. 'Owari' satsuma mandarin was budded on $P$. trifoliata 'Flying Dragon' rootstocks in 3.8L containers in May 2000. The potting medium contained 7 pinebark : 1 sand $(\mathrm{v} / \mathrm{v})$, $18 \mathrm{~N}-2.6 \mathrm{P}-10 \mathrm{~K}$ slow-release fertilizer [8-9 month duration $\left(4.5 \mathrm{~kg} \cdot \mathrm{m}^{-3}\right)$ ], dolomitic lime $\left(2.7 \mathrm{~kg} \cdot \mathrm{m}^{-3}\right)$, and Micromax $\left(0.45 \mathrm{~kg} \cdot \mathrm{m}^{-3}\right)$. Plants were supplemented every $28 \mathrm{~d}$ with water soluble $20 \mathrm{~N}-8.8 \mathrm{P}-16.6 \mathrm{~K}$ and micronutrients, applied through the irrigation system at $234 \mathrm{mg} \cdot \mathrm{L}^{-1} \mathrm{~N}$. Plants were grown outdoors in ambient conditions from 2 May to $23 \mathrm{Aug}$. 2000, at Fairhope, Ala., with daily maximum temperatures ranging from 28.3 to $38.3^{\circ} \mathrm{C}$ and minimums ranging from 15 to $27.2^{\circ} \mathrm{C}$. Shoot growth of test plants varied from 60 to $90 \mathrm{~cm}$ in total length above the graft union. Two acclimation regimes were then initiated. Fifty plants were cold acclimated (CA) in a growth chamber at conditions previously shown to stop active growth, $20^{\circ} \mathrm{C}$ day and $10^{\circ} \mathrm{C}$ night for $14 \mathrm{~d}$, followed by $15^{\circ} \mathrm{C}$ day and $4{ }^{\circ} \mathrm{C}$ night for 14-21 d, with 12-h photoperiod at 400 $\mu \mathrm{mol} P P F$ fluorescent and incandescent light (Yelenosky, 1991). Fifty additional plants (UA) remained outdoors at Fairhope, Ala., for $14 \mathrm{~d}$, with daily maximum temperatures from 32.8 to $38.9^{\circ} \mathrm{C}$, and minimum temperatures of 21.1 to $27.2^{\circ} \mathrm{C}$, and then transferred to a growth chamber at $28^{\circ} \mathrm{C}$ day and $22{ }^{\circ} \mathrm{C}$ night for an additional $28 \mathrm{~d}$. Plants were hand watered throughout the study to maintain moisture levels near field capacity and prevent water stress, but supplemental fertilizer was discontinued for both CA and UA when acclimation regimes were begun.

Freezing procedure. A $0.71-\mathrm{m}^{3}$ chest freezer (Frigidaire, AHP, Augusta, Ga.) was modified and controlled by a computer program to facilitate stable temperature decline. The freezer was equipped with eight, $7.5-\mathrm{cm}$ fans inside slightly larger openings in a false wall at one end of the freezer. Air was pulled from the main chamber by the fans and was passed behind a false wall along the sides of the freezer and out exhaust ports at the opposite end. Heating coils were placed behind the fans and the false wall. During a run, the compressor was left on whereas the heating coils were activated by the computer as often as necessary to control the rate of decline. This system produced a linear decline with the temperature fluctuating at most $\pm 0.2{ }^{\circ} \mathrm{C}$ about the mean (Fig. 1). The computer used two thermocouples positioned on the end wall near the fans to determine the chamber temperature.
Plants were placed upright in the bottom of the freezer in styrofoam wells with fiberglass insulation placed on top of the substrate to prevent freezing of the roots, which was verified by thermocouple placement in the potting medium. The freezer held 10 plants. Plants were placed in the freezer prior to onset of the daytime growth chamber temperature and cooled at the rate of $5^{\circ} \mathrm{C}$ per hour until the air temperature reached $4{ }^{\circ} \mathrm{C}$, and then cooled at $2{ }^{\circ} \mathrm{C}$ per hour. Twelve thermocouples were used at various positions in the main chamber to monitor leaf, stem, and root temperature of test plants. Two adjacent plants were removed at $-4,-6,-8,-10$, and $-12{ }^{\circ} \mathrm{C}$, after the test temperature had been reached for 10 to 15 min. Upon removal from the freezer, the pair of plants was thawed in a $4{ }^{\circ} \mathrm{C}$ cold room for 1 h. One plant from each pair was then dissected and prepared for EL, PL, CG, and TTC assays. The other plant remained at $4{ }^{\circ} \mathrm{C}$ for $11 \mathrm{~h}$, was returned to the cold acclimation chamber for $14 \mathrm{~d}$, and afterward transferred to a greenhouse. Five freezer runs were conducted for each acclimation treatment, which served as replicates, and replicates within each acclimation treatment were run within 1 week to minimize changes in acclimation among the test population. The percent of all leaves killed, and the percent of the length of the shoot killed from the tip to the graft union was determined $90 \mathrm{~d}$ after freezing.

Electrolyte leakage assay. EL was conducted on both leaf and stem tissue. Two 7mm-diameter leaf disks near the mid-vein were removed from each of three mature leaves of the most recent growth flush, and placed in a single, $25-\mathrm{mm}$ test tube containing $20 \mathrm{~mL}$ double distilled water. Six disks were similarly collected from the oldest leaves on the plant and placed in a separate test tube with $20 \mathrm{~mL}$ water. A 1-cm stem section was cut from the oldest growth, characterized by secondary bark

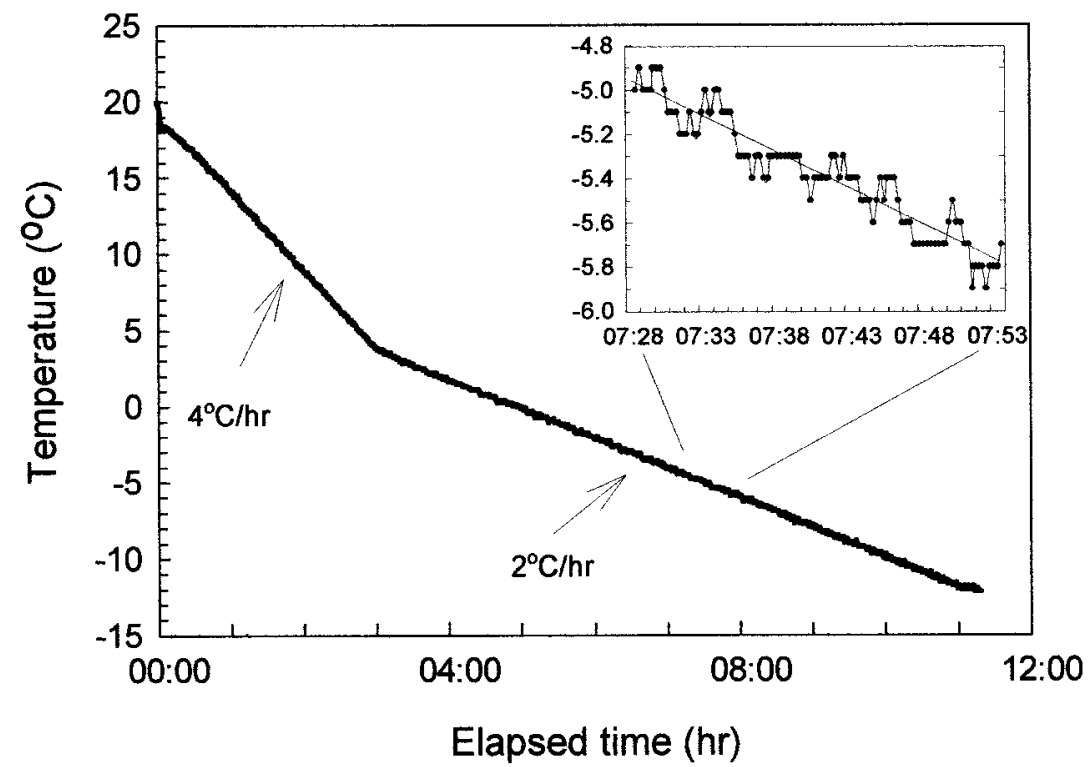

Fig. 1. Temperature measured by a single thermocouple inside the computer-controlled freezing chamber during a test. The computer was programmed to decrease the temperature at $4{ }^{\circ} \mathrm{C} / \mathrm{h}$ and then $2{ }^{\circ} \mathrm{C} / \mathrm{h}$. The inset graph shows that the temperature varied at most by only $\pm 0.2{ }^{\circ} \mathrm{C}$ about the mean at each time interval. The temperature was measured at 16-s intervals. 
formation as indicated by brown-colored streaks. Another $1-\mathrm{cm}$ stem piece was collected from the newest growth flush 10 to 20 $\mathrm{cm}$ from the tip, which was always solid green in color, but not from the most tender, new growth. Each stem piece was placed in a separate test tube with $20 \mathrm{~mL}$ water. All samples were shaken for $24 \mathrm{~h}$ at $20^{\circ} \mathrm{C}$ before measuring with a YSI model 3100 conductivity meter (YSI, Yellow Springs, Ohio). After measurement, samples were autoclaved at $120^{\circ} \mathrm{C}$ for $30 \mathrm{~min}$, shaken for $24 \mathrm{~h}$ at $20^{\circ} \mathrm{C}$, and conductivity was remeasured to determine percent electrolyte leakage of treated vs. killed tissue. EL caused by sample preparation was removed from the data by subtracting the values from plants frozen at $-4{ }^{\circ} \mathrm{C}$ that exhibited no injury. The mean EL data at $-4{ }^{\circ} \mathrm{C}$ was $12.3 \%$ for leaf disks and $11.9 \%$ for stem pieces. In six different studies following the same procedures, unfrozen leaves had mean EL percentage of $10.9 \%$ before autoclaving, and unfrozen stem pieces had $10.4 \%$ EL (data not shown).

Phenolic leakage assay. The same solutions from the EL measurement were used to determine phenolic leakage (PL), following the procedure described by (Chalker-Scott et al., 1989). Two-mL aliquots of sample solution were measured at $260 \mathrm{~nm}$ using a Shimadzu model UV-120-02 UV/VIS spectrophotometer (Shimadzu Precision Instruments, Torrance, Calif.), both before and after autoclaving to determine percent phenolic leakage. PL values were corrected to remove error introduced by sample preparation by subtracting the mean of the $-4{ }^{\circ} \mathrm{C}$ treatment $(7.2 \%$ for leaves and $5.7 \%$ for stems) from values at lower temperatures.

Callus growth assay. A $2.54 \mathrm{~cm}$ long stem section was collected from two locations (new and old growth) on the main stem of sample plants from each acclimation regime. Each section was bisected longitudinally and placed on moist filter paper with the longitudinal cut surface down, and placed in plastic petri dishes subsequently sealed with Parafilm (American Natl. Can., Chicago). Samples were incubated in the dark at 28 to $30{ }^{\circ} \mathrm{C}$ for $7-14 \mathrm{~d}$. The cambium was observed under a dissecting microscope, and the percent of stem sections exhibiting callus growth was determined.

Triphenyl tetrazolium chloride assay. TTC staining was performed on leaf disks and stem segments. Six 7-mm-diameter leaf disks were collected from leaves of the same two ages as for EL and held in separate test tubes containing $10 \mathrm{~mL}$ of $0.25 \%$ TTC in a $0.05 \mathrm{M}$ $\mathrm{Na}_{2} \mathrm{HPO}_{4}-\mathrm{KH}_{2} \mathrm{PO}_{4}$ buffer (pH 7.4). Stem pieces, like those sampled for EL, were dissected to give a thin cross section and two longitudinal sections, and were placed in separate tubes with the stain. Tubes were incubated for a minimum of $48 \mathrm{~h}$ in the dark at $20{ }^{\circ} \mathrm{C}$. After incubation, the pith, xylem, phloem/cambium, and cortex regions were rated alive if stained red. Each of six disks for the leaf samples was individually scored as alive or dead and combined to give a mean score for each sample.

Data from each assay were analyzed as a randomized complete-block design with five blocks, using the GLM procedure of SAS (SAS Institute, 1985).

\section{Results and Discussion}

Survival. Data were initially analyzed by tissue age, but because none of the analyses were significant, data are presented as pooled means for each hardiness and freezing temperature treatment. All leaves and stems were formed within the same 150-d period, which apparently did not provide a sufficient difference in age to affect the level of cold hardiness.

Cold acclimation treatment improved survival of 'Owari' satsuma mandarin $90 \mathrm{~d}$ after treatment compared to unacclimated plants (Fig. 2). At the time freezing treatments were initiated, CA plants had ceased active growth, but UA had not, supporting the findings of Young and Peynado (1962) that cool nighttime temperatures bring about cessation of active growth and greater hardiness. Plants from both acclimation regimes were not visibly injured at $-4{ }^{\circ} \mathrm{C}$, which agrees with other observations on satsuma mandarin (Tignor et al., 1998). Leaf survival of the acclimation regimes at $-10^{\circ} \mathrm{C}$ was similar, and all leaves were killed at $-12{ }^{\circ} \mathrm{C}$.
The amount of stem dieback measured was also affected by acclimation regime, and stems were more resistant to freeze damage than leaves, which has been noted before (Larcher et al., 1973). No stem injury occurred at $-4^{\circ} \mathrm{C}$ or $-6^{\circ} \mathrm{C}$, whether acclimated or not, and all stems were killed at $-12^{\circ} \mathrm{C}$. These findings are in agreement with other freezing studies on satsuma mandarin that place the lowest survival temperature between $-9.4{ }^{\circ} \mathrm{C}$ and $-12{ }^{\circ} \mathrm{C}$ (Anderson et al., 1983; Gerber and Hashemi, 1965; Yelenosky, 1985).

Based on measurements of defoliation and stem dieback, survival of leaves and stems went from $100 \%$ to $0 \%$ within a temperature range of $4{ }^{\circ} \mathrm{C}$ to $6{ }^{\circ} \mathrm{C}$, depending on tissue and hardiness. Many freeze events do not completely kill entire trees, instead causing partial leaf kill and shoot dieback. It would be helpful, therefore, to characterize the range of damage that may occur. Ketchie et al. (1972) proposed determining $\mathrm{T}_{10}$, the temperature that kills $10 \%$ of the test population, and $\mathrm{T}_{90}$, the temperature that kills $90 \%$ of the test population. Physiological studies benefit from both the $T_{10}$ and the $\mathrm{T}_{90}$ by defining a clear range of damaging temperatures. The disadvantage of $\mathrm{T}_{10}$ and $\mathrm{T}_{90}$ is that a full range of temperature should be

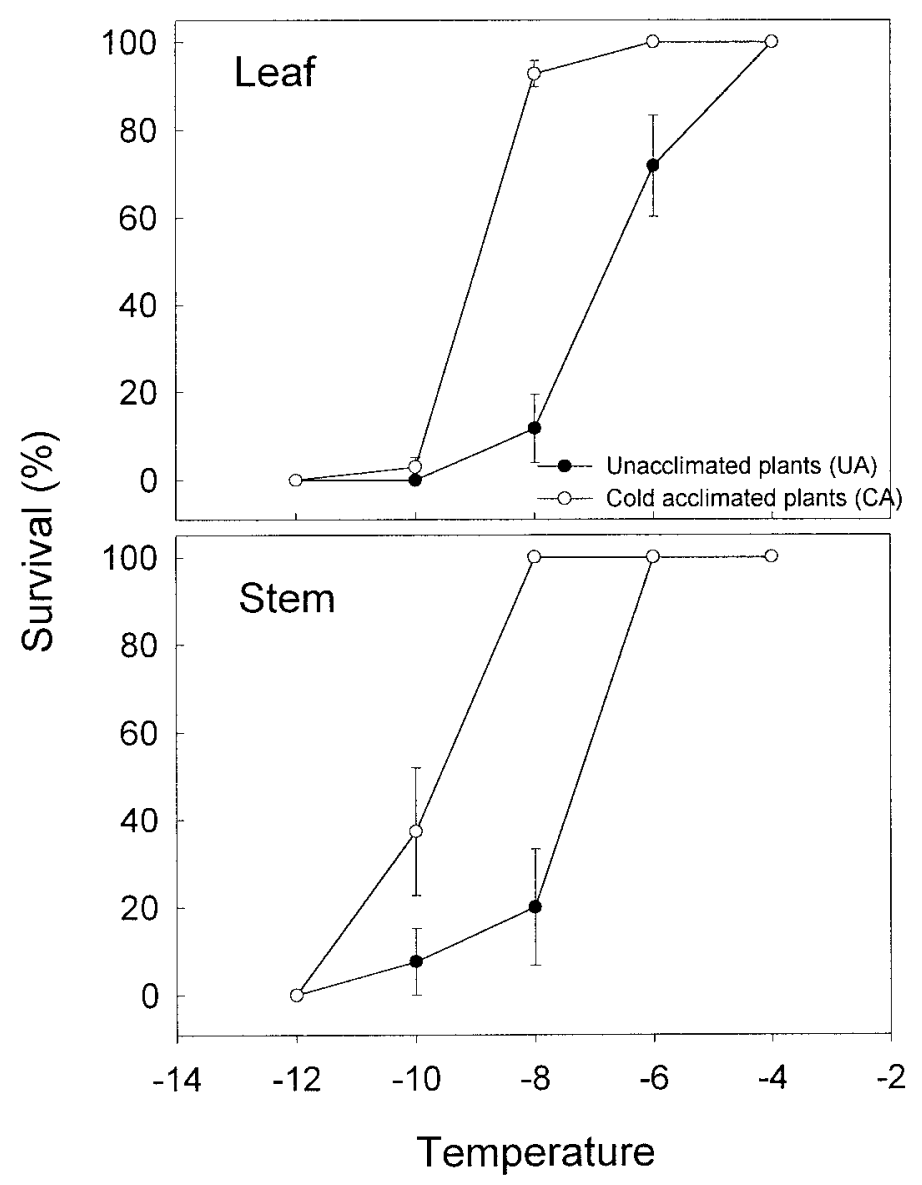

Fig. 2. Survival of cold acclimated (CA) and unacclimated (UA) 'Owari' satsuma mandarin leaves and stems exposed to subfreezing temperatures. Survival was determined after holding the plants in a growth chamber for $14 \mathrm{~d}\left(15^{\circ} \mathrm{C}\right.$ days; $4{ }^{\circ} \mathrm{C}$ nights $)$ and then in ambient or greenhouse conditions for $90 \mathrm{~d}$. Survival is expressed as the percent of all leaves that survived, and the percent of the stem from the tip to the graft union that survived. The vertical bars about the data symbols represent \pm the standard error of the mean. Data symbols with no bars have SE within the height of the data symbol. $\mathrm{n}=5$. 
determined with a particular assay to ensure correct calculation of the temperatures in which a $10 \%$ and $90 \%$ change in an assay occurs. An alternative to the $\mathrm{T}_{10}$ is to determine the highest temperature that yields a significantly different damage or assay value from the control, which has been called the critical temperature $\left(T_{C}\right)$ (Pellett and Heleba, 1998). $T_{C}$ does not require a full range in temperatures for determination and clearly indicates when significant damage occurs, which makes it a better tool for use by growers to determine when to implement freeze protection measures. Although it could be hypothesized that the $\mathrm{T}_{\mathrm{C}}$ and $\mathrm{T}_{10}$ should be very close values, this study demonstrated that they could vary by as much as $1.7^{\circ} \mathrm{C}$ (Table 1 ).

Electrolyte leakage assay. EL of leaves increased with decreasing temperature (Fig. 2 ). EL of CA leaves increased significantly at $-8,-10$, and $-12{ }^{\circ} \mathrm{C}$, compared to -4 and -6 ${ }^{\circ} \mathrm{C}$. EL of UA leaves increased significantly between $-4{ }^{\circ} \mathrm{C}$, the temperature that gave no visual injury, and $-6^{\circ} \mathrm{C}$, and increased significantly again at -8 and $-10^{\circ} \mathrm{C}$, but not at $-12^{\circ} \mathrm{C}$; $-10^{\circ} \mathrm{C}$ was the maximum injury temperature, based on whole plant measurements. $T_{C}$ using EL was similar to $T_{C}$ of whole plants (Table 1). These results support other studies that indicate that the EL assay can be useful for freeze studies on citrus leaves (Tignor et al., 1998).

Unlike leaves, EL of stem tissue did not always increase at temperatures that reduced stem survival on whole plants (Fig 3), and stems were not visibly injured at the EL $T_{C}$ (Table 1). EL of CA stems increased significantly at $-8{ }^{\circ} \mathrm{C}$, but survival was $100 \%$ at that temperature. EL of UA stems increased significantly between -4 and $-6^{\circ} \mathrm{C}$, and between -8 and $-10^{\circ} \mathrm{C}$, but there was not a significant change in survival at those temperatures, providing evidence that some potential for overestimation and underestimation of woody tissue survival does exist with the EL assay, which may be due in part to the diversity in membrane composition of stems.

EL values have not been previously related to whole plant survival of satsuma mandarin, and very few direct comparisons of whole plant survival and EL of citrus have been made. Ketchie (1969) combined EL data from three citrus species; 'Troyer' citrange $[C$. sinensis (L.) Osb. x P. trifoliata (L.) Raf], rough lemon (C. jambhiri Lush.), and 'Keen' sour orange $(C$. aurantium $\mathrm{L}$.), and reported $14 \%$ dieback on cold hardened stems at mean EL values of $39 \%$, and $36 \%$ dieback of unhardened stems at $57 \%$ EL. In another study (Ketchie et al., 1972), EL of 'Keen' sour orange and rough lemon stem pieces was combined into a single survival regression, estimating $\mathrm{T}_{10}$ at $22 \% \mathrm{EL}$ and $\mathrm{T}_{90}$ at $87 \% \mathrm{EL}$. The difference in EL and corresponding survival percentages between the current study and Ketchie et al. (1972), indicates that citrus have inherent differences in membrane permeability that are not affected solely by cold hardiness. Electrical conductivity can be affected by seasonal changes in permeability of living cells (Wilner, 1959). Such changes may reduce the ability of the EL assay to determine

Table 1. Lethal temperatures of 'Owari' satsuma mandarin leaves and stems acclimated to two different temperature regimes and frozen to $-4,-6,-8,-10$, or $-12^{\circ} \mathrm{C}$. The temperatures at which $10 \%$ and $90 \%$ damage of whole plants $\left(\mathrm{T}_{10}\right.$ and $\mathrm{T}_{90}$, respectively) occurred were interpolated from the data in Fig. 1. $\left(T_{C}\right)^{z}$ for whole plant assay, electrolyte leakage (EL), phenolic leakage (PL), callus growth (CG), and triphenyl tetrazolium chloride (TTC) stain of xylem and phloem tissues are shown to compare assay results to actual survival.

\begin{tabular}{|c|c|c|c|c|c|c|c|c|c|}
\hline \multirow[b]{3}{*}{ Organ } & \multirow{3}{*}{$\begin{array}{l}\text { Acclimation } \\
\text { treatment }^{y}\end{array}$} & \multirow{2}{*}{\multicolumn{2}{|c|}{$\begin{array}{c}\text { Whole plant lethal } \\
\text { temp }\left({ }^{\circ} \mathrm{C}\right)\end{array}$}} & \multicolumn{6}{|c|}{$\mathrm{T}_{\mathrm{C}}$ of assays $\left({ }^{\circ} \mathrm{C}\right)$} \\
\hline & & & & \multirow{2}{*}{$\begin{array}{l}\text { Whole } \\
\text { plants }\end{array}$} & \multirow[b]{2}{*}{ EL } & \multirow[b]{2}{*}{ PL } & \multirow[b]{2}{*}{ CG } & \multirow{2}{*}{$\begin{array}{l}\text { TTC of } \\
\text { xylem }\end{array}$} & \multirow{2}{*}{$\begin{array}{l}\text { TTC of } \\
\text { phloem }\end{array}$} \\
\hline & & $\mathrm{T}_{10}$ & $\mathrm{~T}_{90}$ & & & & & & \\
\hline \multirow[t]{2}{*}{ Leaves } & CA & -8.1 & -9.8 & -8 & -8 & -8 & --- & --- & --- \\
\hline & UA & -4.7 & -8.2 & -6 & -6 & -6 & --- & --- & --- \\
\hline \multirow[t]{2}{*}{ Stems } & CA & -8.3 & -11.6 & -10 & -8 & -8 & -8 & -12 & -10 \\
\hline & UA & -6.3 & -9.4 & -8 & -6 & -8 & -10 & -10 & -8 \\
\hline
\end{tabular}

${ }^{2} \mathrm{Tc}$ is the highest temperature at which there was a significant increase in damage or assay result, compared to plants treated at $-4^{\circ} \mathrm{C}$. Plants frozen to $-4{ }^{\circ} \mathrm{C}$ were visually undamaged $90 \mathrm{~d}$ after treatment. Standard errors of means in Figs. 1-5 were compared to determine if differences were significant. ${ }^{\mathrm{y}} \mathrm{CA}=$ cold acclimated, $\mathrm{UA}=$ unacclimated.

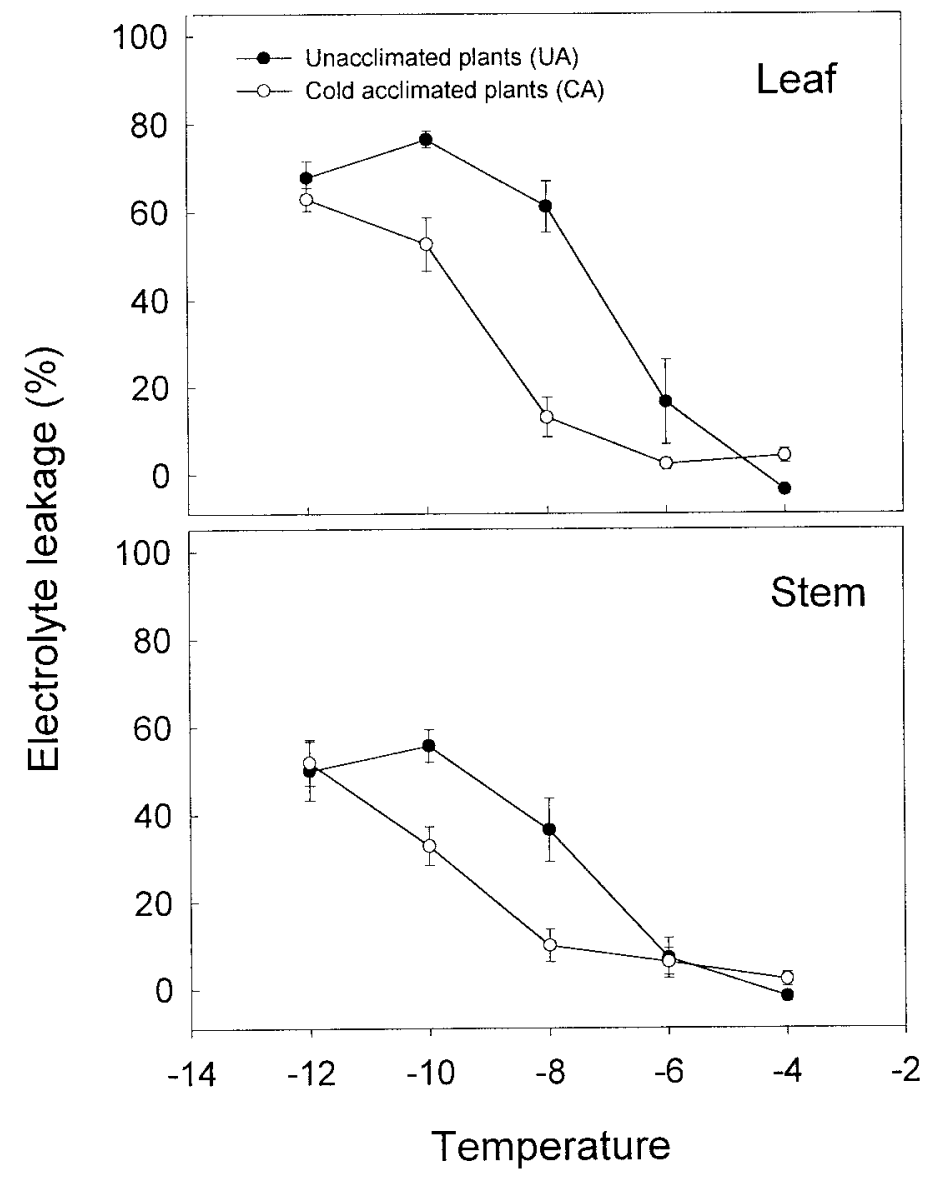

Fig. 3. Electrolyte leakage of leaves and stems of cold acclimated (CA) and unacclimated (UA) 'Owari' satsuma mandarin plants after exposure to subfreezing temperatures. The vertical bars represent \pm the standard error (SE) of the mean. Data symbols with no bars have SE within the height of the data symbol. $\mathrm{n}=5$.

relative differences in cold hardiness among citrus species or cultivars. To make accurate conclusions on survival and injury based on EL alone, controlled studies must be conducted for a particular cultivar under different acclimation regimes, nutritional levels and soil moisture conditions, and the resulting EL percentages compared to whole plant survival.

The results of this study also point out that an EL assay using leaf tissue alone will not accurately predict survival of stem tissue, and vice versa. Anderson (1983), using the inflec- tion point on a sigmoid curve of leaf EL data, found the killing temperature to be $-4{ }^{\circ} \mathrm{C}$ for 'Lisbon' lemon (C. limon Burm. f.) and 'Ruby Red' grapefruit (C. paradisi Macf.), $-7^{\circ} \mathrm{C}$ for 'Valencia' sweet orange, and $-11{ }^{\circ} \mathrm{C}$ for satsuma mandarin. We found only $3 \%$ survival of CA leaves at $-10{ }^{\circ} \mathrm{C}$, but CA stems had $37 \%$ survival at that temperature. Tignor et al. (1998) described the common occurrence of leaves abscising at the petiole-leaf interface on citrus trees after a freeze event, yet studies by Tignor et al. $(1997,1998)$ aimed at measuring changes 
in hardiness with the EL assay, used leaf disks only. While EL assays with leaves may be good for identifying the dynamics in acclimation, omitting stem tissue in the assay limits what conclusions can be drawn about survival of woody tissues, which is of great economic importance to growers. Further work is needed to know whether satsuma mandarin leaves and stems acclimate and deacclimate at the same rate.

Phenolic leakage assay. PL percentages increased with decreasing temperature (Fig. 4). The total percentage of phenolic compounds leaked was lower than the percentages of total electrolytes, and UA tissues leaked more phenolic compounds than CA tissues at each temperature except $-4{ }^{\circ} \mathrm{C}$.

The $\mathrm{T}_{\mathrm{C}}$ for leaves based on PL results was -6 and $-8{ }^{\circ} \mathrm{C}$ for UA and CA leaves, respectively, which was the same $T_{C}$ given by EL. As with EL, significant increases in PL for leaves occurred at temperatures causing significant decreases in leaf survival. Significant increases in PL on CA and UA stems matched whole plant survival decreases as well or better than EL. The $\mathrm{T}_{\mathrm{C}}$ for stems was $-8^{\circ} \mathrm{C}$ for both UA and CA, which was lower than the $\mathrm{T}_{10}$ for UA stems, and the same as the $\mathrm{T}_{10}$ for CA stems. PL is a useful, supportive test as suggested by Chalker-Scott et al. (1989), and was as sensitive as EL. However, PL offers no advantage over EL, because it requires a similar amount of time to perform, and the necessary analytical equipment is more expensive than for the EL assay.

Callus growth assay. Callus was well developed after $7 \mathrm{~d}$ of incubation on CA stems but less so with UA stems. Callus growth on CA stem pieces was significantly higher at -4 and $-6{ }^{\circ} \mathrm{C}$, intermediate at $-8{ }^{\circ} \mathrm{C}$, and not present at -10 and $-12{ }^{\circ} \mathrm{C}$ (Fig. 5). The $\mathrm{T}_{\mathrm{C}}$ for CA stems using $\mathrm{CG}$ was $-8{ }^{\circ} \mathrm{C}$, the same $\mathrm{T}_{\mathrm{C}}$ given by EL and PL (Table 1). Callus formation on UA stem pieces was either not easy to see under a dissecting scope or not present at all after the same incubation time, resulting in no significant difference in callus scores between $-4,-6$, and $-8^{\circ} \mathrm{C}$, resulting in a $\mathrm{T}_{\mathrm{C}}$ of $-10{ }^{\circ} \mathrm{C}$. The reason for the difference found between CA and UA is not clear. Regardless, CG appears to be useful for cold acclimated satsuma mandarin stems only. CG is a slow assay, but it does provide a specific and direct test of the viability of the cambium tissue and stem survival.

Triphenyl tetrazolium chloride assay. Leaf disks developed variable stain patterns, with some having the entire disk stained, while others had a halo of stain on the outer cut edges of the disk, and yet others being variably or partially stained in the center of the disk (data not shown). Variation in leaf cuticle resistance to the stain may be responsible for the different staining patterns. In CA leaves, the temperature with a significant reduction in staining was $-12{ }^{\circ} \mathrm{C}$, whereas the other treatment temperatures were not different indicating that compared to whole plant injury, this method did not predict the highest temperature causing death of leaves. On UA leaves, there was significant difference in the mean TTC scores at -6 and $-8{ }^{\circ} \mathrm{C}$, which was more in agreement with whole plant survival. The TTC stain test does not appear to be a good method for assessing leaf survival because of the difficulty of interpreting the variability in results among leaf disks.
In stem cross-sections, pith and xylem tissues were more resistant to freeze injury than phloem and cortex, which were generally similar (Fig. 6). CA stems had less injury to pith or xylem than UA. The xylem region stained red when whole plant evaluation indicated the

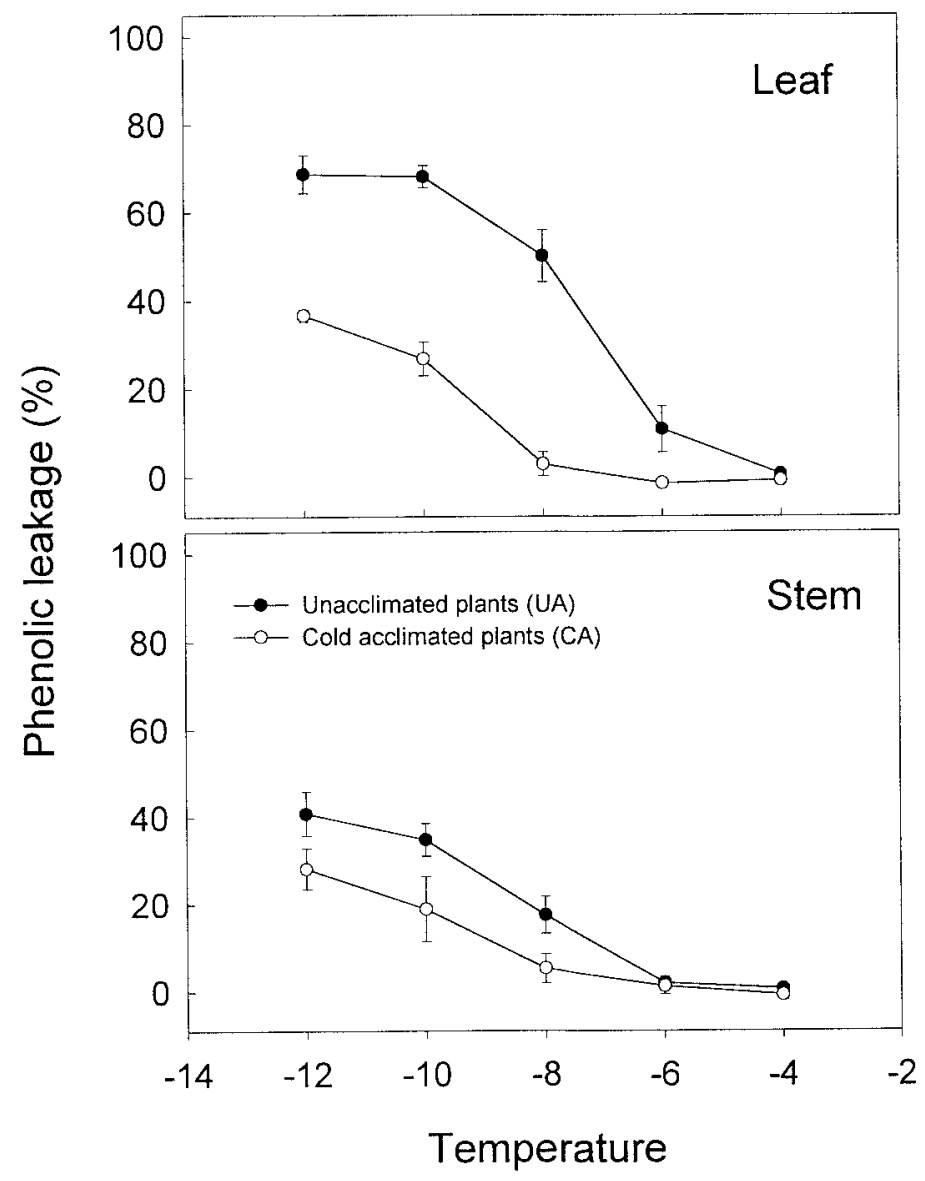

Fig. 4. Phenolic leakage of leaves and stems of cold acclimated (CA) and unacclimated (UA) 'Owari' satsuma mandarin plants after exposure to subfreezing temperatures. The vertical bars represent \pm the standard error of the mean. Data symbols with no bars have SE within the height of the data symbol. $\mathrm{n}=5$.

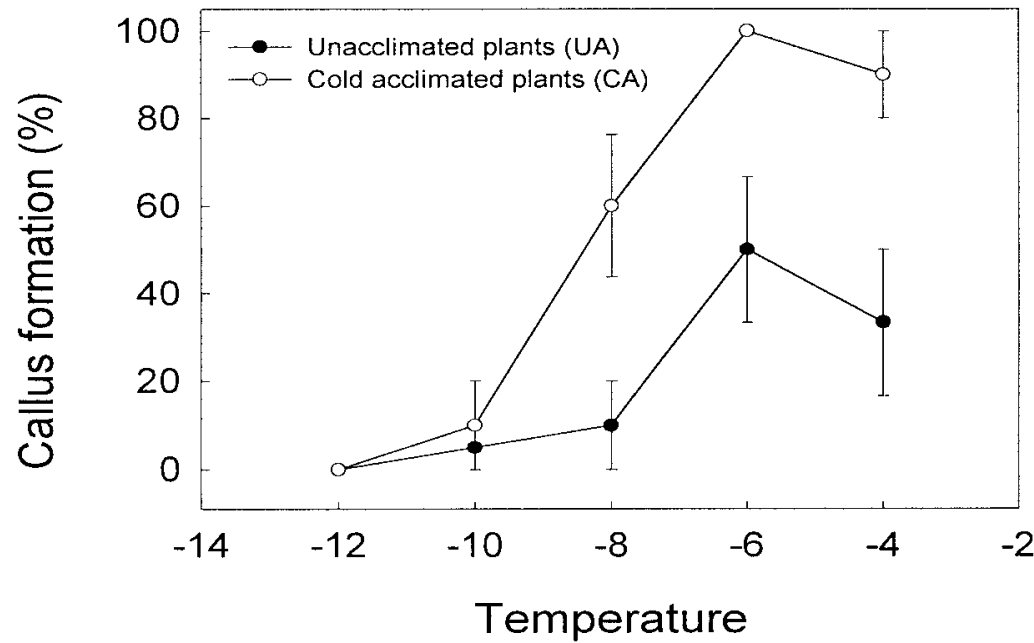

Fig. 5. Percent of stem tissues exhibiting callus formation of cold acclimated (CA) and unacclimated (UA) 'Owari' satsuma mandarin plants after exposure to low temperatures. The vertical bars represent \pm the standard error (SE) of the mean. Data symbols with no bars have SE within the height of the data symbol. $\mathrm{n}=5$. 


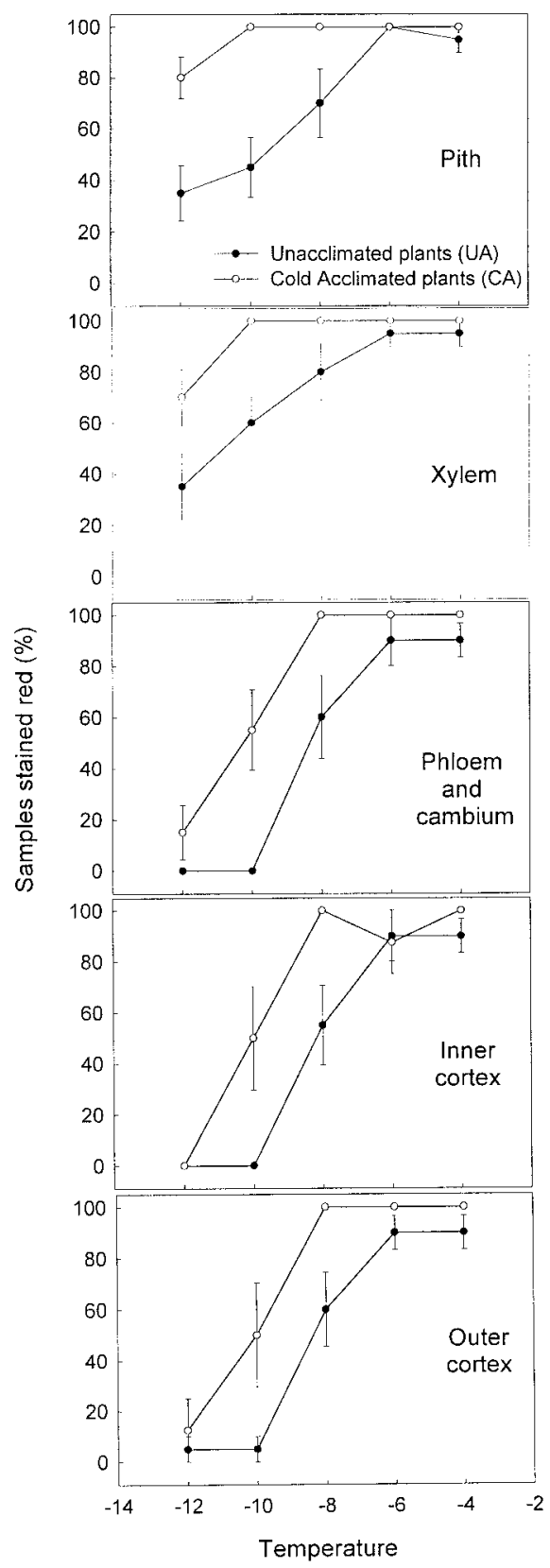

Fig. 6. Triphenyl tetrazolium chloride (TTC) staining of pith, xylem, phloem, inner cortex and outer cortex of cold acclimated (CA) and unacclimated (UA) 'Owari' satsuma mandarin stem cross sections after exposure to subfreezing temperatures. The vertical bars represent \pm the standard error (SE) of the mean. Data symbols with no bars have SE within the height of the data symbol. $\mathrm{n}=5$.

plant had died, as shown by the lower $\mathrm{T}_{\mathrm{C}}$ for xylem compared to the $\mathrm{T}_{\mathrm{C}}$ of whole plants (Table 1). In contrast, the phloem region had significant reduction or lack of staining at the same temperatures that caused death of the stems, and the $T_{C}$ for phloem was the same for each acclimation treatment as the $\mathrm{T}_{\mathrm{C}}$ for whole plant survival.

Phloem and cortex staining was highly correlated with survival of the plant. The cambium, which is critical to survival (Pellett and Heleba, 1998), was likely killed in this study when the phloem was killed, because callus growth occurred on $60 \%$ to $100 \%$ of CA stems when the phloem was $100 \%$ stained, and when phloem staining decreased significantly, callus development was observed on $10 \%$ or fewer stem pieces. The phloem is easily discernible under a dissecting scope, and in this study was a useful indicator for assessing survival; however, the intensity of TTC staining varied within the various tissues, and samples were considered stained across a variety of red hues. Further work is needed to identify how variation in stain intensity of the phloem relates to freeze injury.

In summary, EL and PL were effective assays for measuring survival of satsuma mandarin leaves, whereas TTC was not. The $\mathrm{T}_{\mathrm{C}}$ for EL and PL on frozen leaves were the same, giving the same $T_{C}$ as whole plant survival, regardless of acclimation pretreatment. For both assays, significant increases in electrolytes or phenolics occurred at temperatures when survival decreased. Thus either assay should effectively measure leaf changes in acclimation over time, which agrees with Tignor et al. (1998).

Stem survival was best predicted by the TTC assay of phloem, which gave the same $T_{C}$ as whole plant survival, and had the same significant differences between test temperatures as whole plant survival. Absence of staining of the phloem of stem sections was a reliable indicator of whole plant death. The CG assay was not a reliable assay for unacclimatized woody tissue, and because citrus stems may be constantly acclimating or deacclimating during the winter months, the CG test would not be a good assay for the development of predictive hardiness models. CG also has the disadvantage of being slow to complete.

EL and PL were similar in their ability to detect and predict changes in stem survival. The EL and PL assays are quantifiable and eliminate subjectivity, which is a problem with TTC; however, there is an absence of studies in citrus, relating whole plant response to the results of these assays. This study clearly shows that the level of cold hardiness affects the amount of electrolyte or phenolic leakage in both leaves and stems. Additional variables such as fertility, water relations and tissue age may also affect EL or PL rates at a given point in time. The difference in survival percentages at the same EL percentages between Ketchie et al. (1972) and the current study indicates that different species or cultivars of citrus have different rates of electrolyte leakage that must be considered when drawing conclusions about relative hardiness. Tignor et al. (1998) reported getting occasional aberrant EL values when periodically measuring hardiness, and variation of EL in fruit crops has been reported (Stergios and Howell, 1973). In our study, CA leaves had $93 \%$ survival at $13 \% \mathrm{EL}$, and $0 \%$ survival at $53 \%$ EL, the difference occurring within $2{ }^{\circ} \mathrm{C}$. Good resolution of injury and survival, using these assays is therefore dependent on sampling tissues at one degree or closer intervals.

Instead of predicting specific survival percentages from the EL or PL assays, it may be more practical to follow Pellett and Heleba (1998), and identify the $\mathrm{T}_{\mathrm{C}}$, which does not predict an exact survival percentage as $\mathrm{T}_{10}$ and $\mathrm{T}_{90} \mathrm{do}$, but rather predicts the onset of injury, and takes into consideration those factors like water and nutrition that might affect hardiness. While initial significant increases in EL or PL may be recoverable, the onset of such leakage defines a temperature below which injury will become greater. Knowing that temperature and how it changes throughout the winter would be of economic importance to citrus growers in freeze-prone regions with highly unstable temperature during the winter season.

\section{Literature Cited}

Anderson, J.A., L.V. Gusta, D.W. Buchanan and M.J. Burke. 1983. Freezing of water in Citrus leaves. J. Amer. Soc. Hort. Sci. 108:397-400.

Calkins, J.B. and B.T. Swanson. 1990. The distinction between living and dead plant tissue-viability tests in cold hardiness research. Cryobiology 27:194-211.

Chalker-Scott, L., L.H. Fuchigami, and R.M. Harber. 1989. Spectrophotometric measurement of leached phenolic compounds as an indicator of freeze damage. J. Amer. Soc. Hort. Sci. 114:315319.

Dexter, S.T., W.E. Tottingham, and W.E. Graber 1930. Preliminary results in measuring the hardiness of plants. Plant Physiol. 5:215-223.

Dexter, S.T., W.E. Tottingham, and W.E. Graber. 1932. Investigations of the hardiness of plants by measurement of electrical conductivity. Plant Physiol. 7:63-78.

Emmert, F.H. and F.S. Howlett. 1953. Electrolytic determinations of the resistance of fifty-five apple varieties to low temperatures. Proc. Amer. Soc. Hort. Sci. 62:311-318.

Flint, H.L., B.R. Boyce, and D.J. Beattie. 1967. Index of injury-A useful expression of freezing injury to plant tissues as determined by the electrolytic method. Can. J. Plant Sci. 47:229230.

Fuchigami, L.H. 1996. Cold hardiness, p. 146. In: F.B. Salisbury (ed.). Units, symbols, and terminology for plant physiology: A reference for presentation of results in the plant sciences. Oxford Univ. Press, New York

Gerber, J.F. and F. Hashemi. 1965. The freezing point of citrus leaves. Proc. Amer. Soc. Hort. Sci. 86:220-225.

Hallam, P.M. and W.N. Tibbits. 1988. Determination of frost hardiness of Eucalyptus using the electrical conductivity of diffusate in conjunction with a freezing chamber. Can. J. Forest Res. 18:595-600.

Ketchie, D.O. 1969. Methods of determining cold hardiness and cold injury in Citrus. Proc. $1^{\text {st }}$ Intl. Citrus Symp. Vol 2:559-564.

Ketchie, D.O., C.H. Beeman, and A.L. Ballard 1972. Relationship of electrolytic conductance to cold injury and acclimation of in fruit trees. $\mathrm{J}$. Amer. Soc. Hort. Sci. 97:403-406.

Ketchie, D.O. and R. Kammereck. 1987. Seasonal variation of cold resistance in Malus woody tissue as determined by differential thermal analysis and viability tests. Can. J. Bot. 65:2640 2645.

Kuroda, K., J. Ohtani, and S. Fujikawa. 1997. Supercooling of xylem ray parenchyma cells in tropical and subtropical hardwood species. Trees 12:97-106.

Larcher, W., U. Heber, and K.A. Santarius. 1973. Limiting temperatures for life functions, p. 195231. In: H. Precht, J. Christopherson, and W. 
Larcher (eds.). Temperature and life chapt. III Springer-Verlag, New York.

Palta, J.P., J. Levitt and E.J. Stadelmann. 1977. Freezing injury in onion bulb cells. II. Post thawing injury or recovery. Plant Physiol. 60:398-401.

Parker, J. 1953. Some applications and limitations of tetrazolium chloride. Science 118:77-79.

Parker, J. 1963. Cold resistance in woody plants. Bot. Rev. 29:123-201.

Pellett, N.E. and D.A. Heleba. 1998. Comparing callus growth with discoloration and electrical conductivity as measures of stem injury after freezing woody plants. J. Amer. Soc. Hort. Sci. 123:826-831.

Prasil, I. and J. Zamecnik. 1998. The use of a conductivity measurement method for assessing freezing injury, I. Influence of leakage time, segment number, size and shape in a sample evaluation of the degree of injury. Environ. and Expt. Bot. 40:1-10.

Prive, J. and M.I.N. Zhang. 1996. Estimating cold stress in 'Beautiful Arcade' apple roots using electrical impedance analysis. HortTechnology 6:54-58.

Purcell, A.E. and R.H. Young. 1963. The use of tetrazolium in assessing freeze damage in Citrus trees. Proc. Amer. Soc. Hort. Sci. 83:352-358.

Quamme, H., C. Stushnoff, and C.J. Weiser. 1972. The relationship of exotherms to cold injury in apple stem tissues. J. Amer. Soc. Hort. Sci. 97:608-613.
Redmann, R.E., J. Haraldson, and L.V. Gusta. 1986. Leakage of UV-absorbing substances as a measure of salt injury in leaf tissue of woody species. Physiol. Plant. 67:87-91.

SAS Institute. 1985. SAS/STAT guide for personal computers, vers. 6. SAS Inst., Cary, N.C.

Schaff, D.A., C.D. Clayberg, and G.A. Milliken. 1987. Comparison of TTC and electrical conductivity heat tolerance screening techniques in Phaseolus. HortScience 22:642-645.

Soule, J. 1985. Glossary for horticultural crops. Wiley, New York.

Steponkus, P.L. and F.O. Lanphear. 1967. Refinement of the Triphenyl Tetrazolium Chloride method of determining cold injury. Plant Physiol. 42:1423-1426.

Stergios, B.G. and G.S. Howell, Jr. 1973. Evaluation of viability tests for cold stressed plants. J. Amer. Soc. Hort. Sci. 98:325-330.

Sukumaran, N.P. and C.J. Weiser. 1972. An excised leaflet test for evaluating potato frost tolerance. HortScience 7:467-468.

Tignor, M.E., F.S. Davies, and W.B. Sherman. 1998. Freezing tolerance and growth characteristics of USDA intergeneric Citrus hybrids US 119 and Selection 17-11. HortScience 33:744-748.

Tignor, M.E., F.S. Davies, W.B. Sherman, and J.M. Davis. 1997. Rapid freeze acclimation of Poncirus trifoliata seedlings exposed to $10{ }^{\circ} \mathrm{C}$ and long days. HortScience 32:854-857.

Ting, I.P. 1982. Plant physiology. Addison-Wesley, Reading, Mass.
Towill, L.E. and P. Mazur. 1974. Studies on the reduction of 2,3,5-triphenyltetrazolium chloride as a viability assay for plant tissue cultures. Can. J. Bot. 53:1097-1102.

Wilner, J. 1959. Note on an electrolytic procedure for differentiating between frost injury of roots and shoots in woody plants. Can. J. Plant Sci. 39:512-513.

Yelenosky, G. 1975. Cold hardening in Citrus stems. Plant Physiol. 56:540-543.

Yelenosky, G. 1978. Cold hardening 'Valencia' Orange trees to tolerate $-6.7^{\circ} \mathrm{C}$ without injury. J. Amer. Soc. Hort. Sci. 103:449-452.

Yelenosky, G. 1985. Cold hardiness in citrus, p. 201-238. In: J. Janick (ed.). Hort. Rev. Vol. VII. AVI Publ. Co., Westport, Conn.

Yelenosky, G. 1991. Supercooling and freezing in the main stem of Valencia orange trees. Cryobiology 28:382-390.

Yelenosky, G. and G. Horanic. 1969. Subcooling in wood of Citrus seedlings. Cryobiology 5:281283.

Young, R. 1970. Induction of dormancy and cold hardiness in Citrus. HortScience 5:411-413.

Young, R. and A. Peynado. 1962. Growth and coldhardiness of Citrus and related species when exposed to different night temperatures. Proc. Amer. Soc. Hort. Sci. 81:238-243.

Zhang, M.I.N. and J.H.M. Willison. 1986. An improved conductivity method for the measurement of frost hardiness. Can. J. Bot. 65:710715 . 